\title{
Differential Growth and Development Response of Sunflower Hybrid in Contrasting Irrigation Regimes
}

\author{
Amjed Ali ${ }^{1}$, Ijaz Rasool Noorka ${ }^{1,2^{*}}$ \\ ${ }^{1}$ University College of Agriculture, University of Sargodha, Sargodha, Pakistan; ${ }^{2}$ Molecular and Cytogenetic Lab, University of \\ Leicester, Leicester, UK. \\ Email: *ijazphd@yahoo.com
}

Received March $4^{\text {th }}, 2013$; revised April 17 th $^{\text {th }}$ 2013; accepted May 10 $0^{\text {th }}, 2013$

Copyright (C) 2013 Amjed Ali, Ijaz Rasool Noorka. This is an open access article distributed under the Creative Commons Attribution License, which permits unrestricted use, distribution, and reproduction in any medium, provided the original work is properly cited.

\begin{abstract}
Water is the most important factor limiting crop productivity at different growth stages of crop growth and development. The study was conducted to investigate the effect of irrigation scheduling on sunflower hybrid (Hysun-38) at vegetative versus reproductive stages during spring season 2010. The trial was laid out in randomized complete block design (factorial arrangement), replicated thrice, having net plot size of $3.5 \mathrm{~m} \times 9 \mathrm{~m}$. The treatments comprised of irrigation application of $75 \mathrm{~mm}$ each, at different growth and development stages. viz., $\mathrm{I}_{1}=$ irrigation at plant establishment, $\mathrm{I}_{2}=$ irrigation at plant establishment and irrigation at vegetative phase, $\mathrm{I}_{3}=$ irrigation at plant establishment, irrigation at button stage and irrigation at flowering, and $\mathrm{I}_{4}=$ irrigation at plant establishment, irrigation at vegetative phase, irrigation at button stage and irrigation at achene's formation. Days taken to $50 \%$ flowering was highest in $\mathrm{I}_{2}$, where irrigation was applied at plant establishment and vegetative phase, and in $\mathrm{I}_{4}$ treatment, where irrigation was given at seedling establishment, irrigation at vegetative phase, irrigation at button stage and irrigation at achene's formation. Leaf area index at different growth intervals was significantly affected by irrigation levels. Crop growth rate was highest for treatment $\mathrm{I}_{4}$. Plant height $(\mathrm{PH})$, stem girth $(\mathrm{SG})$ head diameter (HD), 1000-achene's weight (AW) and achene's yield (AY) were significantly affected by different irrigation levels at various growth stages. Maximum AY $\left(2415.68 \mathrm{~kg} \cdot \mathrm{ha}^{-1}\right)$ was obtained in $\mathrm{I}_{4}$ treatment while, minimum AY $\left(1275.35 \mathrm{~kg} \cdot \mathrm{ha}^{-1}\right)$ was obtained in case of those plots which were irrigated only at plant establishment stage. Sunflower productivity was affected with irrigation regime at different growth stages with the strongest responses seen at early growth stages which ultimately affected the final achene yield adversely.
\end{abstract}

Keywords: Growth; Irrigation; Leaf Area Index; Yield

\section{Introduction}

Sunflower (Helianthus annus L.) is a non-conventional oilseed crop and it is grown on an area of 1108 thousand acres with seed and oil production of 643 and 244 thousand tons, respectively, during the year 2009-2010 in Pakistan GOP [1], which is very low as compared to other countries. Application of irrigation at critical stages of plant growth not only regulates the metabolic process in plants but also increase effectiveness of other inputs and increases the crop yields. Chowdhry et al., [2], Noorka et al. [3-5]. Both amount and distribution of water has a significant effect on yield in sunflower, Krizmanic et al., [6]; Reddy et al., [7]; Iqbal et al., [8]. Maximum yield of sunflower was obtained with irrigation at all critical growth stages, while most important when applied

\footnotetext{
*Corresponding author.
}

during flowering and yield formation periods, Stone et al., [9]. However, according to other scientists initial plant growth stages are more important for adequate water than to later irrigations (Tolga and Lokman [10]). Seed and oil yield were significantly affected by deficit Irrigation during critical growth period of a crop (Kazemeini et al. [11]). The deficiency of water modifies soil water relationship by lowering tissue water potential and improving metabolic process (Akhtar et al., [12]). Water stress during vegetative growth reduces leaf area and dry matter due to decrease in leaf water potential from less water update of more atmospheric demand, severely influences the leaf expansion. The most sensitive stages of sunflower to moisture stress are flowering, achene formation (Chimenti, et al. [13]). Khaziaie, et al., [14], Mehrpouyan et al., [15], Bakht et al., [16], Mirshekari et 
al., [17] concluded that irrigation deficit at late growth stages has less effect on yield than at early growth stages. The limited irrigation stress resulted in reduction of seed yield due to limited vegetative and reproductive development.

The present study, therefore, was carried out to determine the response of sunflower crop to irrigation distribution interval as regard to different growth and developmental stages for harvesting maximum economic return of sunflower.

\section{Materials and Methods}

\subsection{Experimental Site}

The experiment was conducted at the research farm of University College of Agriculture, Sargodha, Pakistan (320.04'N, 720.08'E) during spring season 2010. Randomized complete block design was used in experiment, replicated thrice, having net plot size of $3.5 \mathrm{~m} \mathrm{x} 9 \mathrm{~m}$. The soil was silty loam and composite sample to a depth of $30 \mathrm{~cm}$ was obtained from experimental area and was analyzed (Nitrogen $=0.06 \%$, available Phosphorus $=$ $5.43 \mathrm{ppm}$ and potassium $240 \mathrm{ppm}$ ). Hybrid Hysun-38 of sunflower was planted on ridges in the pattern of $70 \mathrm{~cm}$ ridge spaced and maintained $22.5 \mathrm{~cm}$ plant spacing, using a seed rate of $7 \mathrm{~kg} \cdot \mathrm{ha}^{-1}$.

\subsection{Irrigation Application}

The experiment comprised of four treatments viz.

$\mathrm{I}_{1}=$ irrigation at plant establishment.

$\mathrm{I}_{2}=$ irrigation at plant establishment + irrigation at vegetative phase.

$\mathrm{I}_{3}=$ irrigation at plant establishment + irrigation at button stage + irrigation at flowering.

$\mathrm{I}_{4}=$ irrigation at seedling establishment + irrigation at vegetative phase + irrigation at button stage + irrigation at achenes formation.

Each irrigation amount was of $75 \mathrm{~mm}$ and applied by flooded method in ridges. Mean monthly weather data for sunflower growing season March-June in 2010 (Table 1).

\subsection{Fertilizer Application}

Half of total nitrogen and full dose of phosphorus was applied at the time of field preparation by broadcast method in urea and diammonium phosphate form, respectively, while remaining $1 / 2$ of nitrogen was applied after 30 days of sowing of crop. Whole dose of Potassium was also given as a basal @ $50 \mathrm{~kg}$ ha in the form of potassium sulphate. All other cultural and agronomic practices except under study were same for all the treatments. Thinning was done after 15 days of crop emergence to maintain required plant population.

\subsection{Methodology}

The observations recorded were; days taken to flowering, leaf area index, crop growth rate, plant height at maturity, stem girth, head diameter, thousand achene weight and achene's yield. Ten plants were randomly selected and tagged in each plot for measurement of phonological data. LAI-2200 plant canopy analyzer was used in the field for non-destructive leaf measurement.

\subsection{Statistical Analysis}

The data were thus collected for various growths and yield parameters and statistically analyzed by employing the Fisher's analysis of variance technique and then treatments means were compared least significant difference (LSD) test at 0.05 level of probability (Steel et al., [18]).

\section{Results and Discussions}

\subsection{Days Taken to Flowering}

Figure 1 showed that number of days taken to $50 \%$ flowering (60.03) were maximum in I2 treatment where the crop was irrigated twice at plant establishment and vegetative phase against the minimum days (50.32) in $I_{1}$, where the crop was irrigated only at plant establishment. But $\mathrm{I}_{2}$ treatment remained statistically at par with $\mathrm{I} 4$ treatment where crop was irrigated at seedling establishment, vegetative phase, button stage, and at achenes for mation stage. Increase in number of days to flowering

Table 1. Mean monthly weather data for sunflower growing season March-June in 2010.

\begin{tabular}{|c|c|c|c|c|}
\hline Months & $\begin{array}{c}\text { Maximum Temperature } \\
\left({ }^{\circ} \mathrm{C}\right)\end{array}$ & $\begin{array}{c}\text { Minimum Temperature } \\
\left({ }^{\circ} \mathrm{C}\right)\end{array}$ & Total Rainfall (mm) & Mean relative humidity (\%) \\
\hline February & 20.5 & 8.3 & 7.11 & 60.3 \\
\hline March & 27.4 & 14.1 & 9.2 & 58.5 \\
\hline April & 37.7 & 23.4 & 4.06 & 44.2 \\
\hline May & 39.6 & 25.3 & 2.04 & 44.9 \\
\hline June & 40.01 & 26.5 & 14.74 & 44.6 \\
\hline
\end{tabular}




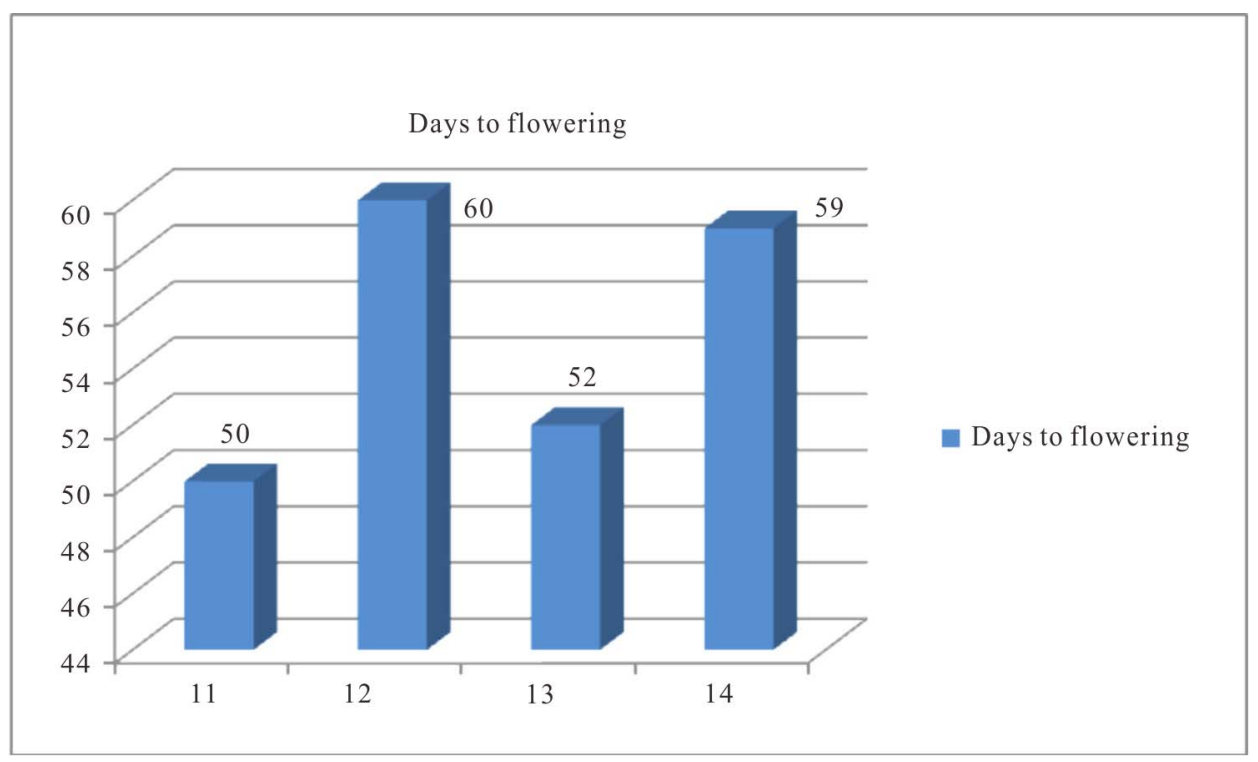

Figure 1. Effect of irrigation schedule on sunflower phenology.

may be due to the fact that application of water at vegetative stage increased vegetative growth and delayed flowering. These findings are in line with those of Jana et al., [19]; Teama \& Mahmoud [20].

\subsection{Leaf Area Index (LAI)}

Figure 2 represents the effect of treatments on LAI development during the growing season. Figure shows that LAI was significantly affected by irrigation levels. First data obtained after 20 days of sowing showed non-significant difference for all the treatments. However maximum LAI (2.10) was recorded after 40 days of sowing for I4 treatment which was statistically at par with I2 treatment. These results are in line with findings of Ghani et al., [21] who reported decrease in LAI with increase in sporadic water stress.

\subsection{Crop Growth Rate (g-2d-1)}

The data regarding the effect of different irrigation levels have been presented in Figure 3. Regarding irrigation, the highest growth rate (14.07) was recorded in $\mathrm{I}_{4}$ treatment and followed by $\mathrm{I}_{3}$ and $\mathrm{I}_{2}$ treatments, which were statistically at par with each other while minimum crop growth rate was (8.13) in $I_{1}$ treatment where irrigation was given only at plant establishment.

\subsection{Plant Height at Maturity (cm)}

The data regarding the plant height at harvest affected by different levels of irrigation are given in Table 2. Maximum plant height was recorded in $\mathrm{I}_{4}$ treatment which is statistically at par with $\mathrm{I}_{2}$ treatment against the minimum plant height (146.4) in I1 where the crop was irrigated only at plant establishment. In irrigation levels, maxi- mum stem girth (1.694) was recorded in $\mathrm{I}_{4}$ treatment followed by $I_{2}$ and $I_{3}$ treatment while minimum stem girth was obtained in $I_{1}$ where crop was irrigated only at plant establishment stage. The increase in stem girth may be attributed to optimum irrigation levels at crop developmental stages which primarily produced more stem girth. Similar results were also reported by Iqbal [22], Mirshekari [17] and found that application of water at establishment and vegetative stages increase vegetative growth of sunflower.

\subsection{Yield Components and Achene Yield $\left(\mathrm{kg} \cdot \mathrm{ha}^{-1}\right)$}

Head diameter is one of the most important factors affecting yield and production potential of sunflower, the data pertaining to head diameter has been presented in table which reveal that maximum head diameter (15.67) was noted for I4 treatment where the crop was irrigated at all the critical stages of irrigation, which did not differ significantly from $I_{3}$ and $I_{2}$ treatments where head diameter (15.00) and (14.37) was recorded respectively, while minimum head diameter (12.85) was found in $\mathrm{I}_{1}$ treatment where irrigation was applied only at crop establishment stage. Irrigation levels had significant influence on seed weight and the highest 1000-achene weight (65.43) was recorded in $\mathrm{I}_{4}$ treatment against the minimum 1000-achene weight (38.20) in $I_{1}$ where the crop was irrigated once at plant establishment. These results are similar with the findings of, Unger et al., [23], Akhtar et al., [12] and Baksh et al., [24], who reported increase in 1000-achene weight with application of water at flowering and seed development stages. Data given in Table $\mathbf{2}$ showed that achene yield was significantly influenced by different irrigation levels. It increased significantly 


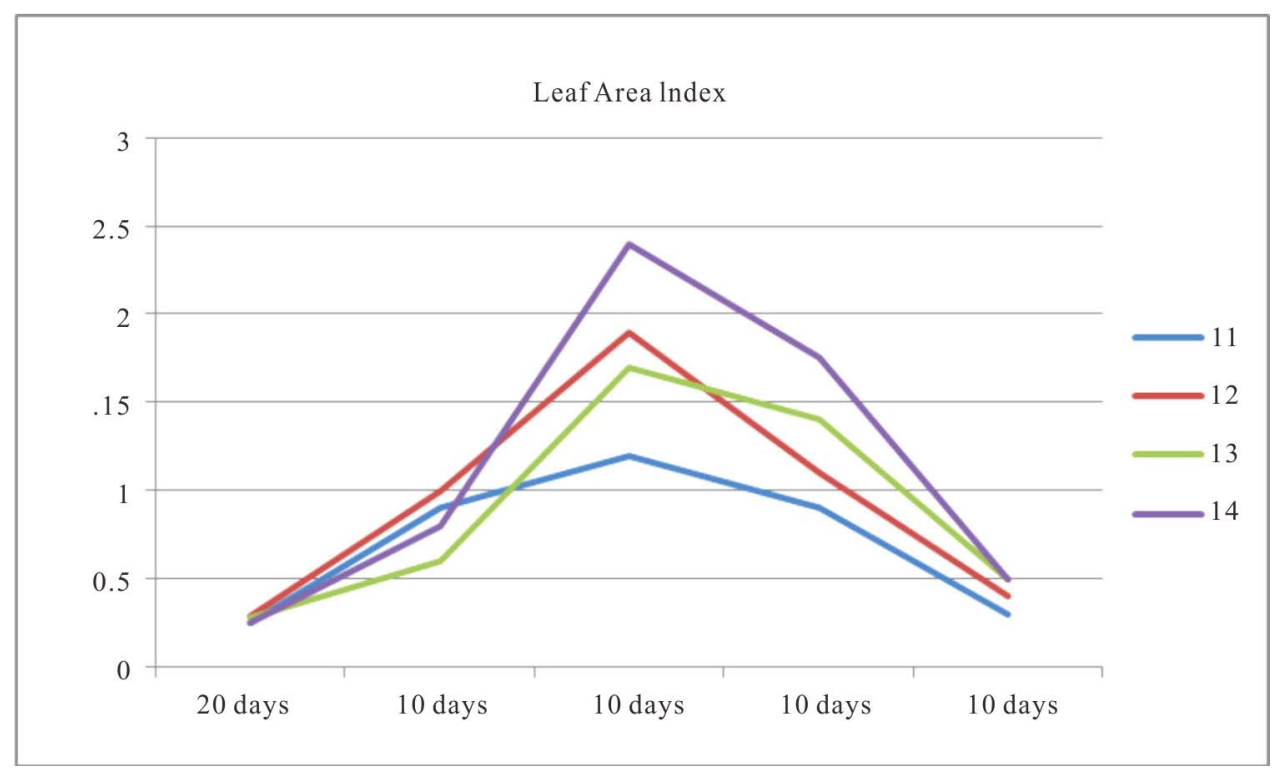

Figure 2. Sunflower leaf area index at different growth interval affect by irrigation scheduling.

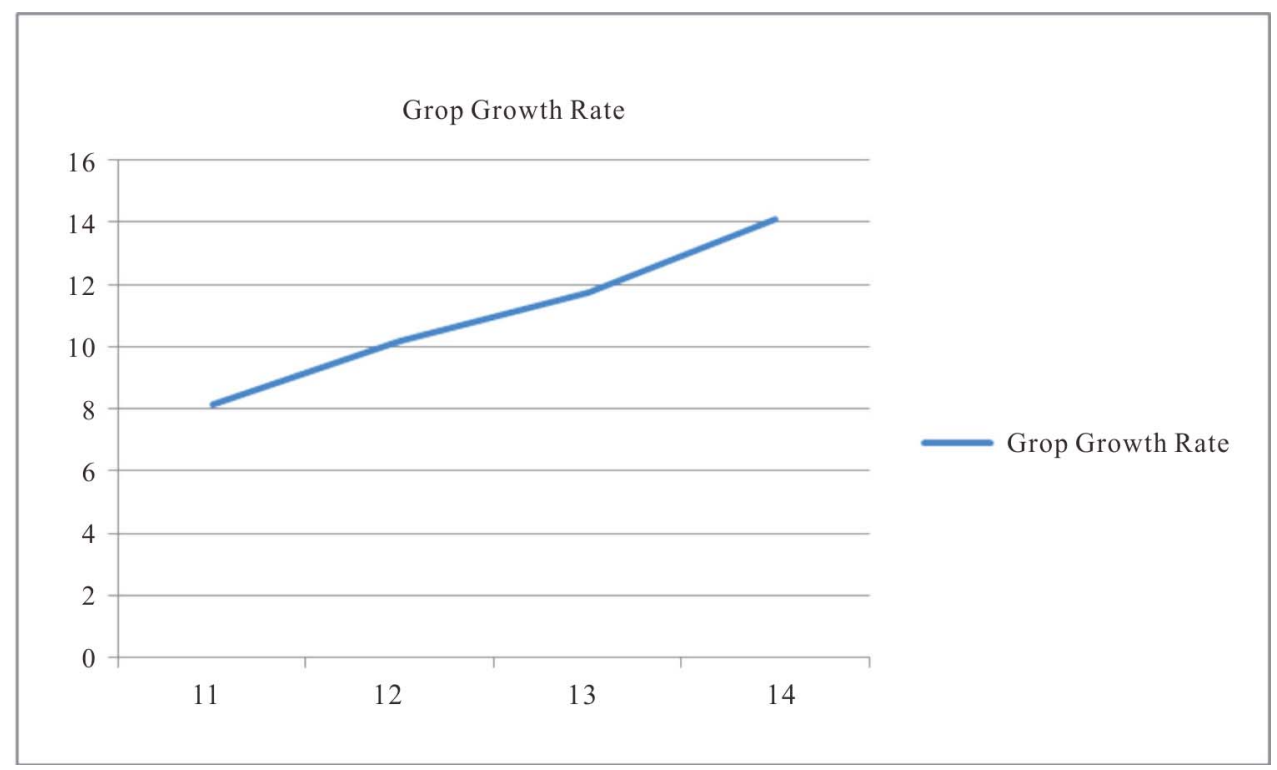

Figure 3. Crop growth rate as affected by different irrigation levels.

Table 2. Effect of different levels of irrigation on growth and yield parameters sunflower hybrid.

\begin{tabular}{cccccc}
\hline $\begin{array}{c}\text { Treatments. } \\
\text { (irrigation schedules) }\end{array}$ & $\begin{array}{c}\text { Plant height at } \\
\text { maturity }(\mathrm{cm})\end{array}$ & Stem girth $(\mathrm{cm})$ & $\begin{array}{c}\text { Head diameter } \\
(\mathrm{cm})\end{array}$ & $\begin{array}{c}1000 \text { - achene's } \\
\text { Weight }(\mathrm{g})\end{array}$ & $\begin{array}{c}\text { Achene yield } \\
\left(\mathrm{kg} \cdot \mathrm{ha}^{-1}\right)\end{array}$ \\
\hline $\mathrm{I}_{1}$ & $141.4 \mathrm{c}$ & $1.432 \mathrm{c}$ & $12.85 \mathrm{~b}$ & $38.20 \mathrm{~d}$ & $1275.35 \mathrm{~d}$ \\
$\mathrm{I}_{2}$ & $157.2 \mathrm{a}$ & $1.522 \mathrm{~b}$ & $14.37 \mathrm{ab}$ & $50.12 \mathrm{c}$ & $1563.36 \mathrm{c}$ \\
$\mathrm{I}_{3}$ & $149.0 \mathrm{~b}$ & $1.568 \mathrm{~b}$ & $15.00 \mathrm{a}$ & $57.36 \mathrm{~b}$ & $1876.29 \mathrm{~b}$ \\
$\mathrm{I}_{4}$ & $160.3 \mathrm{a}$ & $1.694 \mathrm{a}$ & $15.67 \mathrm{a}$ & $65.42 \mathrm{a}$ & $2415.68 \mathrm{a}$ \\
$\mathrm{LSD}$ & 6.55 & 0.09524 & 1.653 & 5.321 & 180.22 \\
\hline
\end{tabular}

At $5 \%$ level of probability (LSD), any two means not sharing a letter differ significantly. 
from (1275.35) to (2015.68) in treatment $I_{1}$ and $I_{4}$ treatment, respectively. There is an increase in yield of $47.20 \%$ of treatment $\mathrm{I}_{4}$ over Treatment $\mathrm{I}_{1}$, where irrigation was applied only at plant establishment stage. These findings are in line with those of Teama \& Mahmoud [20] and Reddy et al., [7]; Andhale \& Kalbhor [25] and ValadAbadi et al., [26], Noorka [27], Bakht et al., [16], Mirshekari et al., [17] who reported that proper irrigation scheduling increases the grain yield in crop. The preservation and improvement of genetic diversity of field crop will be helpful in maintaining the best genotypes, Tadesse1 et al. [28], Gomez-Pando and Barra [29], Noorka, et al. [30], Safdar et al. [31]

\section{Conclusion}

Sunflower responded to irrigation stop at different growth and developmental stages and strongest response was seen at early growth stages. For obtaining maximum achene's yield of sunflower the crop should be irrigated $\left(\mathrm{I}_{4}\right)$ at seedling establishment, irrigation at vegetative phase, irrigation at button stage and irrigation at achene formation. Deficit irrigation, during critical growth and development periods should be avoided. Further research may be required in this area for sunflower crop to identify the irrigation scheduling effects for obtaining higher economic return.

\section{Acknowledgements}

The authors are grateful to Dr. Abdur Rahman, Professor Emeritus, Ex-Vice Chancellor, University of Agriculture, Faisalabad, Pakistan, for his continuous guidance $\&$ technical support to conduct the study.

\section{REFERENCES}

[1] Government of Pakistan, "Agricultural Statistics of Pakistan (2010-11)," Government of Pakistan, Ministry of Food, Agriculture and Livestock, Economic Wing, Islamabad, 2011.

[2] M. A. Chowdhry, I. Rasool, I. Khaliq, T, Mehmood and M. M. Gilliani, "Genetics of Some Metric Traits in Spring Wheat under Normal and Drought Environments," Rachis, Vol. 18, No. 1, 1999, pp. 34-39.

[3] I. R. Noorka, I. Khaliq, Z. Akram and S. Iqbal, "Inheritance Studies of Physio-Genetic Traits in Spring Wheat under Normal and Moisture Stress Environments," International Journal of Agriculture and Applied Sciences, Vol. 1, No. 1, 2009, pp. 29-34.

[4] I. R. Noorka, S. Rehman, J. R. Haidry, I. Khaliq, S. Tabassam and M. Din, "Effect of Water Stress on PhysicoChemical Properties of Wheat (Triticum aestivum L.)" Pakistan Journal of Botany, Vol. 41, No. 6, 2009, pp. 2917-2924.

[5] I. R. Noorka, A. Batool, S. AlSultan, S. Tabasum and A. Ali. "Water Stress Tolerance, Its Relationship to Stem
Reserve Mobilization and Potence Ratio in Spring Wheat,' American Journal of Plant Sciences, Vol. 4, No. 2, 2013, pp. 231-237. doi:10.4236/ajps.2013.42030

[6] M. Krizmanic, I. Liovic, A. Mijic, M. Bilandzic and G. Krizmanic, "Genetic Potential of Sunflower Hybrids in Different Agro-Ecological Conditions," Sjemenarstvo, Vol. 20, No. 5-6, 2003, pp. 237-245.

[7] G. K. M. Reddy, K. S. Dangi, S. Kumar and A. V. Reddy. "Effect of Moisture Stress on Seed Yield and Quality in Sunflower," Journal of Oilseeds Research, Vol. 20, No. 2, 2003, pp. 282-283.

[8] N. Iqbal, M. Ashraf and F. Azam, "Effect of Oxygenous Application of Glycine betaine on Capitulumn Size and Achene Number of Sunflower under Water Stress," International Journal of Biology and Biotechnology, Vol. 2, No. 3, 2005, pp. 765-771.

[9] L. R. Stone, A. J. Schlegel, R. E. Gwin and A. H. Khan. "Response of Corn, Grain Sorghum and Sunflower to Irrigation to the High Plains of Kansas," Agriculture and Water Management, Vol. 30, No. 3, 1996, pp. 251-259. doi:10.1016/0378-3774(95)01226-5

[10] E. Tolga and D. Lokman, "Yield Response of Sunflower to Water Stress under Tekirdag Conditions," Helia, Vol. 26, No. 38, 2003, pp. 149-158. doi:10.2298/HEL0338149E

[11] S. A. Kazemini, M. Edalat and A. Shekoofa, "Interaction Effects of Deficit Irrigation and Row Spacing on Sunflower Growth, Seed Yield and Oil Yield," African Journal of Agricultural Research, Vol. 4, No.11, 2009, pp. 1165-1170.

[12] M. Akhtar, M. Zubair, M. Saeed and R. Ahmed, "Effect of Planting Geometry and Water Stress on Seed Yield and Quality Planted Sunflower," Pakistan Journal of Agricultural Science, Vol. 30, No. 1, 1993, pp. 73-76.

[13] C. Chimenti, A. Pearson and H. Hall. "Osmotic Adjustment and Yield Maintenance under Drought in Sunflower," Field Crops Research, Vol. 75, No. 2-3, 2002, pp. 235-246. doi:10.1016/S0378-4290(02)00029-1

[14] H. R. Khaziaie, N. Nadjafi and M. Bannayan, "Effect of Irrigation Frequency and Planting Density on Herbage Biomass and Oil Production of Thyme Hyssop," Industrial Crops and Production, Vol. 27, No. 3, 2008, pp. 315-321. doi:10.1016/j.indcrop.2007.11.007

[15] M. Mehrpouyan, G. Nazari and S. Sayfzadea, "Effect of Irrigation Stop at Different Growth Stages on Some Agronomic Traits of Sunflower under Three Plant Densities in Takestan Region, Iran," Plant Ecophysiology, Vol. 2, 2010, pp. 137-144.

[16] J. Bakht, S. Mohammad, Y. Mohammad, Raziuddin and A. K. Mohammad, "Effect of Irrigation on Physiology and Yield of Sunflower Hybrids," Pakistan Journal of Botany, Vol. 42, No. 2, 2010, pp. 1317-1326.

[17] M. Mirshekari, M. H. Nasser, A. Reza and R. Z. Omid, "Study the Effects of Planting Date and Low Irrigation Stress on Quantitative Traits of Spring Sunflower," Romanian Agricultural Research, Vol. 29, 2012, pp. 189199. 
[18] R. G. D. Steel, J. H. Torrie and D. A. Dicky, "Principles and Procedures of Statistics. A Biological Approach," Mcgraw Hill Brook Co., New York, 1997, pp. 336-354.

[19] P. K. Jana, B. Musra and P. K. Kar, "Effect of Irrigation at Different Physiological Stages of Growth and Yield Attributes, Yield Consumptive Use and Water Use Efficiency of Sunflower," Indian Agriculturist, Vol. 26, No. No. 1, 1982, pp. 39-42.

[20] E. A. Teama and A. M. Mahmood, "Response of Sunflower to Watering Regimes and Nitrogen Fertilizer," Asian Journal of Agricultural Sciences, Vol. 25, No. 5, 1994, pp. 39-46.

[21] A. Ghani, M. Hussain and M. S. Qureshi, "Effect of Different Irrigation Regimes on the Growth and Yield of Sunflower," International Journal of Agriculture and Biology, Vol. 2. No. 4, 2000, pp. 334-335.

[22] J. Iqbal, "Growth, Yield and Oil Contents of Sunflower as Influence by Irrigation and Nitrogen Supply," M.Sc. Thesis, Department of Agronomy, University of Agriculture, Faisalabad, 1990.

[23] P. W. Unger. "Irrigation Effect on Sunflower Growth, Development and Water Use," Field Crop Research, Vol. 7, 1983, pp. 181-194. doi:10.1016/0378-4290(83)90021-7

[24] I. Baksh, U. Awan and M. S. Baloch, "Effect of Various Irrigation Frequencies on Yield and Yield Components of Sunflower," Pakistan Journal of Biological Sciences, Vol. 2, No. 1, 1999, pp. 194-195. doi:10.3923/pjbs.1999.194.195

[25] R. K. Andhlae and P. N. Kalbhor, "Patterns of Dry Matter Accumulation of Sunflower as Influenced by Irrigational Schedules under Various Levels of Nitrogen Fertilization," Journal of Maharashtra Agriculture University, Vol. 5.
No. 1, 1981, pp. 9-14.

[26] A. R. Valad-Abadi, A. Moradi-Aghdam, J. Daneshiyan, H. R. Zakeri, M. Ghafari and M. Roshdi, "Effect of Plant Density on Plant Phenology and Some Agronomical Traits of Sunflower in Water Deficit Condition," Plant and Ecosystem, Vol. 13, 2008, pp. 86-103.

[27] I. R. Noorka, "Sustainable Rural Development and Participatory Approach by On-Farm Water Management Techniques," In: Sustainable Agricultural Development, Springer, New York, 2011, pp. 139-146. doi:10.1007/978-94-007-0519-7 9

[28] T. Tadesse1, N. Dechassa, W. Bayu and S. Gebeyehu, "Effects of Farmyard Manure and Inorganic Fertilizer Application on Soil Physico-Chemical Properties and Nutrient Balance in Rain-Fed Lowland Rice Ecosystem," American Journal of Plant Sciences, Vol. 4, No. 2, 2013, pp. 309-316. doi:10.4236/ajps.2013.42041

[29] L. R. Gomez-Pando and A. Eguiluz-de la Barra, "Developing Genetic Variability of Quinoa (Chenopodium quinoa Willd.) with Gamma Radiation for Use in Breeding Programs," American Journal of Plant Sciences, Vol. 4, No. 2, 2013, pp. 349-355. doi:10.4236/ajps.2013.42046

[30] I. R. Noorka and S. A. Shahid, "Use of Conservation Tillage System in Semiarid Region to Ensure Wheat Food Security in Pakistan," Development in Soil Salinity Assessment and Reclamation, Springer Book, 2013. http://www.springer.com/environmrnt/soil+science/book/ 978978-94-007-5683-0

[31] M. E. Safdar, I. R. Noorka, A. Tanveer, S. A. Tariq and S. Rauf, "Growth and Yield of Advanced Breeding Lines of Medium Grain Rice as Influenced by Different Transplanting Dates," The Journal of Animal \& Plant Sciences, Vol. 23, No. 1, 2013, pp. 227-231 